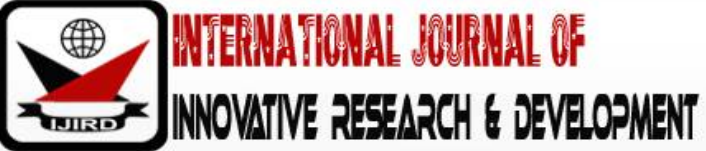

ISSN 2278 - 0211 (Online)

\section{Kenyan Technical Students' Views on the Role of Kiswahili in Technical Education}

\author{
Jackson Mutuku Kavoi \\ Ph.D. Candidate, Department of Languages, Linguistics and Literature, \\ School of Arts and Social Sciences, Rongo University, Kenya \\ Ernest Sangai Mohochi \\ Associate Professor, Department of Kiswahili and Other African Languages \\ Kibabii University, Kenya \\ Carren Nyandiba \\ Senior Lecturer, Department of Languages, Linguistics and Literature, \\ School of Arts and Social Sciences, Rongo University, Kenya
}

\begin{abstract}
In Kenya, Kiswahili is taught in almost all levels of education, both in public and private institutions, except technical institutes. Therefore, its role is not explicitly explored in these institutions. However, it plays uncategorized important roles by the sidelines of the technical education curriculum and therefore, its importance cannot be underrated. It is out of this realization that this study, embarks on establishing the views of students of technical institutes on the importance of Kiswahili language in technical education. The research adopted a descriptive survey design, sampling 148 students and 20 instructors from 5 technical institutions. The study used questionnaires and structured interview guides to collect data. The content analysis method was majorly used to analyze the data obtained. The findings revealed that Kiswahili plays a very important role by the sidelines of the technical education curriculum. Currently, Kiswahili is not the medium of instruction in technical institutes, however course instructors, use it to expound complex concepts, especially among the certificate students. Additionally, it is widely used in academic discussions when students are preparing for internal and external examinations. Also, counselors use it as a guidance and counseling tool, and it is the preferred language for service delivery in the field among other roles. This study also found out that Kiswahili is the language of communication among the students. Out of these important roles played by Kiswahili as revealed by the students, this study recommends that the Ministry of Higher Education Science and Technology (MOHEST), in collaboration with the Kenya Institute of Curriculum Development (KICD) works on a strategy to introduce teaching of Kiswahili language as a subject to technical institutes' students. By so doing, they will be supporting the academic and social roles that Kiswahili plays by the sidelines of the technical education curriculum. Finally, further research can be conducted on the comparison of attitudes of technical institutes' students towards both Kiswahili and English in view of using Kiswahili as the medium of instruction among certificate students.
\end{abstract}

Keywords: Technical institutes, Kenyan technical students, Kiswahili, technical education, students' views

\section{Introduction}

Language is a discrete combinatorial system used by human beings for the purposes of communicating (Kirk, 2005). In the simplest terms, language can be defined as a system of arbitral sounds, used by a particular linguistic community for the purposes of communication among themselves. In a nutshell, language is a way of communicating, as well as, a thinking tool, hence used to exchange ideas. Language is also used to transfer knowledge from one place to another. Trudgil (1974) observes that "language can be a very important factor in ...identifying a group.... It can as well affect a society by influencing or even controlling the world-view of its speakers" (Pp 24). Out of this insight, we may conclude that language is a very important tool in catalyzing development among its speakers (Ipara and Mbori, 2009).

In view of the fact that a language can be used to transfer knowledge, then it follows that Kiswahili, being one of the world's languages having more than 100 million speakers throughout Africa, cannot be ignored in matters of development (Payne, 2014). Moreover, Payne avers that, Kiswahili is a language used in business, the national language in Kenya, Uganda, Tanzania, and Democratic Republic of Congo, Inter-African trade language associated with Information Technology (IT), arts and culture, a Lingua Franca and used by many foreign media organizations such as BBC, VOA and Deutsche Welle. Even more, Kiswahili is a tool of communication, as well as a symbol of regional identity and integration of people of East Africa and their cultures (Habwe, 2018). Besides, Kiswahili has about 5 million first-language speakers (Webb \& Kembo-Sure, 2000).

Since the colonial era, English language has been enjoying a higher status compared to Kiswahili. According to Nabea (2009), despite Kiswahili having more than 80\% speakers in Kenya in comparison to the English which has less 
than $25 \%$, its status has been low. This may be why the English language and Communication Skills in English are taught almost in all institutions of higher learning including technical institutes. Also, English has been a medium of instruction and the official language until after the promulgation of the new 2010 Kenyan constitution, when Kiswahili too assumed the role of official language. However, this role has yet to take effect in many government offices as observed by Nyandwaro (2015). This seems to reflect a situation of paying lip-service to the Kiswahili language with nothing significant happening on the ground, at least from the government side since a lot is happening among users of the language.

Further, the Kiswahili language has been experiencing mixed fortunes in technical education. This is because in the 1990's Communication Skills in Kiswahili was at one time taught to certificate students in technical institutes, but was later withdrawn. On the other hand, the Kiswahili language received attention only in the certificate and craft levels, being taught only to students pursuing Social Work and Community Development course (Field, 2017). This is an indication that the Kiswahili language has a role to play in the social and educational set up of the technical institutes. It is out of this understanding that this study was carried out to establish the views of the technical students on the role of Kiswahili language towards technical education because they are key stakeholders.

\section{Literature on Related Studies}

This section deals with literature on technical and vocational education training globally, both developed and developing countries, including a few African countries. It also presents literature on the role of Kiswahili language in education in Kenya, Uganda and Tanzania.

Technical and vocational education training is a skill-oriented form of education where students acquire knowledge on various skills geared towards production of certain professionals, for example, electricians, plumbers, masons, plant operators among others. How this training is acquired and accomplished varies from place to place. In the United Kingdom, vocational education and training comprise the classroom-based education, workplace education, and apprenticeships which combines the two (City \& Gilds group, n. d.). In its research which dealt with economic benefits of vocational education and training in the UK, it established that with the increase of vocational skills, the UK economy may go up to 163 billion pounds in the next 10 years. However, it found out that there were barriers to these gains. These included the complexity of the vocational qualification system and lack of investment skills on the part of both the employer and individuals involved. To counter these barriers, it proposed that information should be availed to young people about Vocational Education Training (VET) opportunities. In addition, this group's research advanced the need to stabilize the skills and employment sector to avoid the imbalance in overproducing or under producing graduates from various VET institutions.

City \& Gilds group (n. d.) conducted a similar research on economic benefits of vocational education and training in India and established that, India appreciates the need to enhance the skills of its workforce for better economic growth. The study further found out that VET forms a small part of the education system whereby $2.3 \%$ of the workforce having acquired formal skill training. It also found out that apprenticeships are able to contribute to the Indian economy. Through the use of International Labor Organization analysis on the basis of several case studies of small businesses, it established increased earnings pegged to apprenticeships which was more than the corresponding costs. However, just like the UK, VET in India faced several challenges. These included traditional and cultural practices which favored white-color jobs and non-review of obsolete skill curricula. Also, low levels of enrolment and poor formal apprenticeship program design cited as some of the challenges. To deal with some of these challenges barring accrual of benefits, it proposed first to deal with the inherent stigma associated with vocational education through employer engagement in encouraging the youth to take up VET opportunities exposed to them. Our study is quite different from what was done in United Kingdom (UK) and India. It is not geared towards financial gains of Technical and Vocational Education Training (TVET), but to establish the importance of Kiswahili language by the sidelines of the technical education curriculum in Kenya.

In Africa, specifically in Ghana, Amedorme and Fiagbe (2013) conducted a research which sought to establish the challenges facing Technical and Vocational Education Training (TVET). Their study revealed several challenges which bedeviled TVET in Ghana. These problems ranged from deficit in the availability of technical institutes to lack of training facilities. Other challenges included inadequate instructors and negative public attitude towards technical and vocational training education in Ghana. To deal with these challenges, the study proposed directors of National Vocational Training Institute Centers, rectors of Polytechnics, vice-chancellors of Technology Universities, professional bodies, professionals from industries, educationists, policy makers and civil society groups to sit round table and assess the problem of job progression related to technical and vocational training and device a method of dealing with it for good. Additionally, they proposed to the government to construct more technical institutions proportionally distributed across the country. Further, they recommended the government to provide free technical education to the qualifiers and post them after training, to public jobs so as to encourage them take up technical and vocational education seriously. In addition, the establishment of a College of Technology Education (COTE) to train instructors for technical education was proposed.

Swaziland Economic Policy Analysis and Research (SEPARC) (2018), just like City \& Gilds group, undertook a research, to find out the monetary gains of Technical and Vocational Education and Training (TVET) in the Kingdom of Swaziland using National Handcraft Training Centre (NHTC) as a case study. It established that TVET may reduce the unemployment rate significantly by 2022, since the graduates acquire skills that enable them to join the labor market immediately after they graduate, by being employed directly or employing themselves. It advanced that $73.1 \%$ of those who graduated joined gainful employment after completing their studies from NHTC; whereby $47.6 \%$ were absorbed in the formal sector, while $25.5 \%$ employed themselves. However, it added that $26.2 \%$ could not be employed between the period1995-2015. Studies of SEPARC and City \& Gilds group involving The Kingdom of Swaziland and UK, India 
respectively dealt with economic matters concerning TVET while our study was language based. These were different studies; the only point of convergence being the institutions involved in the study.

In the Kenyan scenario, technical institutes are centers of training to artisans and middle level technicians, conferring certificates and diplomas respectively. Ngerechi (2003) defined technical training at four levels: Youth Polytechnics and Jua Kali artisans, craft artisans from Technical Training Institutes (TTIs) and Institutes of Technology (ITs), technicians from National Polytechnics (NPs) and a few selected TTIs and ITs and technologists from NPs and universities. The study at hand did not involve artisans from Youth Polytechnics (Vocational Training Centers) and students from technical universities. Moreover, Ngerechi's study took audit of entry requirements in these institutes and found out that female students were discriminated against, especially in technical courses. Similarly, the study of Kimani, Mueni and Wango (2015) echoed Ngerechi's views. Their study sought to establish the challenges female students in technical institutes faced and also found out that female students were discriminated in courses considered for males, for example, the motor vehicle and electrical engineering. Equally, a study by Murgor, Chang'achi and Keter (2014) sought to establish the challenges experienced by physically challenged persons who joined technical institutes. They found out that, just like female students, they were discriminated in construction of hostels, whereby their physical challenges were not taken into consideration when the hostels were being designed.

Concomitantly, Muyela (2012) conducted a study which differed with the above discussed studies. This study sought to establish the infrastructure of technical institutes in Kenya, including whether their instructors were attached to any industries. However, the results were in the negative. The study also found out that the instructors never received any training programs to sharpen their job skills. In a related area, Kigwilu, Ala and Wambua (2016) sought to establish the challenges which hampered implementation of the curriculum in Catholic-sponsored institutes and how to deal with them. Their results showed that lack of resources, students' attitudes towards the courses they were pursuing and non-payment of tuition fees and lack of recreational facilities contributed to failure of curriculum implementation. So far, out of all these studies none dealt with Kiswahili language or Communication Skills in Kiswahili issues, hence the need to address the importance of Kiswahili language to technical education.

More so, Kiswahili scholars are of the view that the role of Kiswahili is very broad because it is used nationally as well as internationally. For example, Kihore (1983), Kiango (2002) and Kandagor (2014) are of the view that Kiswahili unites countries within the Great Lakes region. Keiko (2014) also advances that Kiswahili brings together Japan and the East African countries. According to Kihore (1983) and Kiango (2002), Kiswahili is a language of instruction in various institutions. These, include primary schools and primary teachers training colleges at certificate level in Tanzania. Furthermore, it is used as a medium of instruction in technical institutes, certificate artisans and certificate level in Tanzania. Similarly, Kiswahili is a compulsory subject in Kenya and Tanzania at secondary level. Kandagor (2014) is of the view that Kiswahili can unite the East African countries in the fields of religion, business, administration, education and the media. Ipara and Mbori (2009) in their study, conclude that Kiswahili can be a language of technology, as exemplified by Asian languages in the fields of technology.

Mukuthuria (2006) examined the role of Kiswahili in Uganda, which can be summed up thus, of late, Kiswahili is being taught in primary schools and some universities, for example, Kyambogo, Makerere and Islamic University of Mbale. Also, he avers that it acts as the second official language of Uganda after English. More so, he is of the opinion that attitudes towards Kiswahili in Uganda are gradually changing from negative to positive. Generally, all the above reviewed studies, evaluated the role of the Kiswahili language in various fields, however, they did not unmask the role of Kiswahili in technical training education, which is addressed in this study.

\section{Research Methodology}

This study used the descriptive survey design whereby the respondents were required to answer questions administered in the questionnaires and interviews. Afterwards, the respondents' responses were described. The descriptive survey design is expected to be valid and reliable, if the questions are constructed properly, for the purposes of clarity and easy understanding (Kothari, 2004). In this regard, our questions were closed-ended, open-ended and partially open-ended so as extract the desired information from the respondents.

A targeted population of 991 students from 5 national polytechnics was involved. These institutions included: Kabete National Polytechnic, Kenya Coast National Polytechnic, Kisii National Polytechnic, Meru National Polytechnic and The Eldoret National Polytechnic. Through random sampling, a sample size of 148 respondents was chosen for the study. However, only 142 filled the questionnaires appropriately and were used for data analysis. Six questionnaires got spoilt and were therefore discarded. The respondents were drawn from second year certificate students and third year diploma students, who were finalists in their programs. 20 instructors, 4 from each institution were involved in the study.

A questionnaire and a structured interview schedule were used to collect data. These instruments were tailored to generate data on the role of Kiswahili in technical education. The areas of concern were: where Kiswahili language was used in the institutions of study, importance of Kiswahili to these institutions, as well as, service delivery outside the institutions.

Data was analyzed through content analysis method. Basically, content analysis allows data collected to be processed in a systematic and reliable manner and afterwards generalizations made in relation to the requirements of the study (Jackson, 2009). In this case, the qualitative method was used to deduce and interpret the meaning of the content within texts. In a nut-shell, content analysis bridged the gap between the qualitative and the quantitative approaches in analyzing data (Jackson, 2009). To avoid subjective impressions in our data, inter-coder reliability was done for the purposes of reliability in analysis of our data. In this regard, there was agreement in the data posted by the two coders, hence reliability assured. 


\section{Findings and Discussion}

Our study entirely involved 148 respondents, however only 142 were used in the data analysis. These comprised of arts and science students in technical institutes in Kenya. The arts students formed $48.59 \%(n=69)$ and science $51.41 \%$ $(n=73)$. The age of the respondents ranged between $<20$ years to $>35$ years. The majority of the respondents ranged between 20 to 25 years, translating to $77 \%(n=107)$. Those at the age of $<20$ formed $14 \%(n=20)$, while those aged between 26 to 30 years were $7 \%(n=10) ; 31$ to 35 years and $>35$ years were $1 \%(n=1)$ respectively. This distribution is shown in table 1 below.

\begin{tabular}{|c|c|c|}
\hline $\begin{array}{c}\text { Characteristics } \\
\text { (Age And Specialization) }\end{array}$ & Number of Respondents (n) & Percentage (\%) \\
\hline Age & & \\
\hline$<20$ & 20 & 14 \\
\hline $20-25$ & 107 & 77 \\
\hline $26-30$ & 10 & 7 \\
\hline $31-35$ & 1 & 1 \\
\hline$>35$ & 1 & 48.59 \\
\hline Specialization & 69 & 51.41 \\
\hline Arts & 73 & \\
\hline Science & & \\
\hline
\end{tabular}

Table 1: Demographic Characteristics of Respondents in Technical Institutions Source: Field, 2017

Table1above gives the demographic characteristics of the respondents involved in our study. It was derived from various courses gravitating towards arts and science, based on service delivery and purposively chosen. The respondents were drawn from arts and science specializations. This data depicts the science respondents $(51.41 \%)$ were more compared to the arts respondents (48.59\%). This is because proportionally, science students are more as opposed to the arts, since the technical institutions are science-oriented. As for the age characteristic, the respondents were majorly young ranging between 20 to 25 years.

The courses which were involved in the study were those gravitating towards service delivery and their distribution is reflected in figure 1 below.

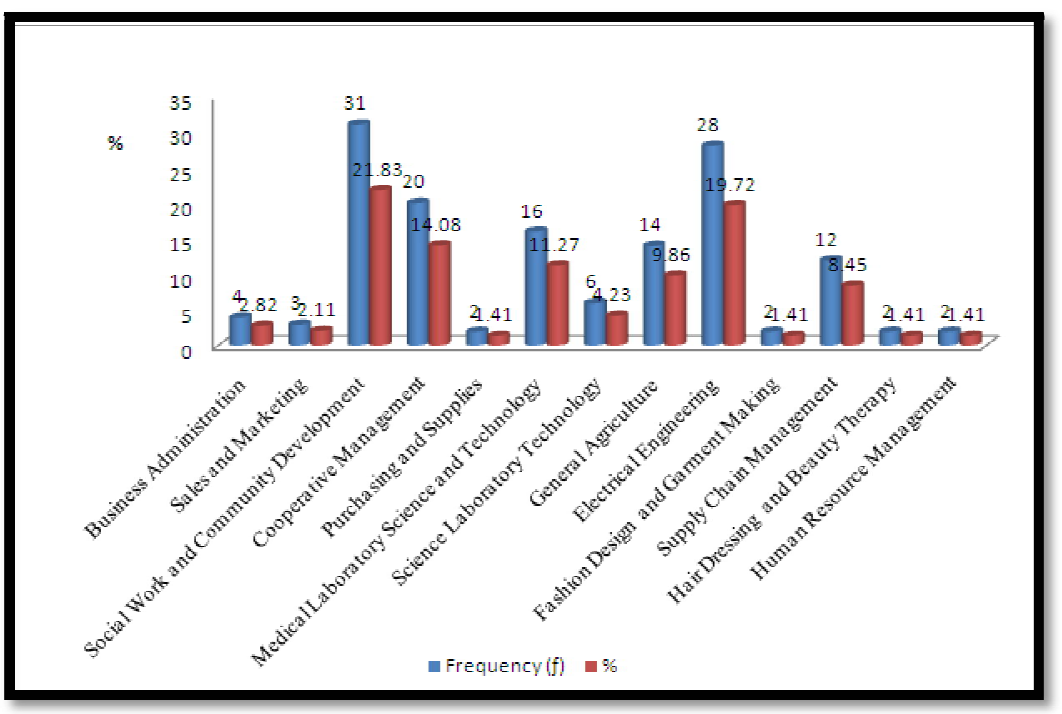

Figure 1: Percentage Distribution of Selected Courses Based on the Service Delivery

Figure 1 above shows the distribution of selected courses based on service delivery. These are Social Work and Community Development having a share of $21.83 \%(n=31)$, followed closely by Electrical Engineering having $19.72 \%$ $(\mathrm{n}=28)$. Other courses having sizeable numbers included Cooperative Management 14.08\% ( $\mathrm{n}=20)$ and Medical Laboratory Science and Technology $11.27 \%(n=16)$. These are followed by courses having average numbers and they include Supply Chain Management 8.45\% ( $\mathrm{n}=12)$ and General Agriculture 9.86\% ( $\mathrm{n}=14)$. Courses which had negligible numbers of respondents included Business Administration 2.82\% $(n=4)$, Sales and Marketing $2.11 \%(n=3)$, Purchasing and Supplies $1.41 \%(n=2)$ and Human Resource Management 1.41\% $(n=2)$ which are arts related courses. The science related ones were Science Laboratory Technology 4.23\% $(n=6)$, Fashion Design and Garment Making 1.41\% $(n=2)$ and Hair Dressing and Beauty Therapy 1.41\% ( $\mathrm{n}=2)$. Therefore, 13 courses ( 7 arts and 6 science service-related courses) were involved in the study; chosen purposively as service courses. 
The number of respondents was proportional to the total population of technical students. From the above data, it can be noted that some courses are more popular than others, for example, Social Work and Community Development 21.83\%, Electrical Engineering 19.72\%, Cooperative Management 14.08\% and Medical Laboratory Science and Technology $11.27 \%$.

\subsection{Students' Views on the Importance of Kiswahili in Technical Education}

The main objective of this study was to find out the views of technical students pursuing various courses towards the importance of Kiswahili language in technical education. To achieve this objective, the study was required to answer the question, "What views do students pursuing various courses in technical institutes have on the role of Kiswahili language in relation to technical education?" To deal with this question, the respondents' responses, who were students from technical institutes, were analyzed through content analysis method. Out of these responses, it was concluded that Kiswahili was important to technical students' education. On the sidelines, it was used to expound difficult terms, a tool of guidance and counseling, language of service delivery and academic discussions, language of communication among the students and the support staff and a support subject to Social Work and Community Development course at the certificate level. Further, the respondents were required to state the language used in various areas in their institutes. These areas included offices, meetings, notice boards, principal's assembly speeches and in sporting activities. The table below reflects the language used in various areas in technical institutes.

\begin{tabular}{|c|c|c|c|c|c|c|}
\hline \multirow{2}{*}{ Various Areas } & \multicolumn{6}{|c|}{ Language Used in Various Areas in (\%) } \\
\cline { 2 - 7 } & \multicolumn{2}{|c|}{ English } & \multicolumn{2}{c|}{ Kiswahili } & \multicolumn{2}{c|}{ Total } \\
\cline { 2 - 7 } & $f$ & $\%$ & $f$ & $\%$ & $f$ & $\%$ \\
\hline Office & 116 & 82.86 & 24 & 17.14 & 140 & 100 \\
\hline Meetings & 105 & 75.00 & 35 & 25 & 140 & 100 \\
\hline Notice boards & 89 & 64.03 & 50 & 35.97 & 139 & 100 \\
\hline Principal's assembly speeches & 113 & 81.88 & 25 & 18.12 & 138 & 100 \\
\hline Sports activities & 27 & 19.42 & 112 & 80.58 & 139 & 100 \\
\hline
\end{tabular}

Table 2: The Language Used in Various Areas in Technical Institutions Source: Field, 2017

From table 2 above, it can be deduced that, the commonly used languages in technical institutes were mainly English and Kiswahili and their uses can be categorized into two: official and non-official. It is clear that, English is mainly used in official matters touching office, meetings, notice boards, speeches from the principals during assemblies, while Kiswahili is used in non-official matters like sporting activities. Despite the fact that Kiswahili was declared as an official language during the promulgation of the Kenyan constitution in 2010, English remains the major official language. Otherwise, $82.86 \%(\mathrm{n}=116)$ of the respondents stated that the language used in the offices was English, while $17.14 \%$ $(\mathrm{n}=24)$ stated it was Kiswahili. In meetings, $75 \%(\mathrm{n}=105)$, notice boards $64.03 \%(\mathrm{n}=89)$ and speeches from the principals was $81.88 \%(\mathrm{n}=113$ ). This in a nut-shell, showed English was broadly used in the areas mentioned earlier which are official in nature, while Kiswahili was used in non-official areas like sports. 80.58\% $(n=112)$ of the respondents intimated that Kiswahili was mostly used during sporting activities when the students were cheering and officiating matches. Our study presents a similar case to a previous study by Nyandwaro (2015) which found out that, despite Kiswahili being declared in the 2010 constitution as one of the official languages, English remains the official language in entirely all Kisii County Offices.

Apart from Kiswahili being used widely in sports, it was established that Kiswahili had other roles gravitating towards technical institutes' curriculum and non-curriculum issues. These roles are tabulated in table 3 below in order of preference.

\begin{tabular}{|c|c|c|}
\hline Other roles of Kiswahili & frequency (f) & Percentage (\%) \\
\hline Expounding concepts & 38 & 27.14 \\
\hline Guidance \& Counseling & 29 & 20.71 \\
\hline Use in service delivery & 22 & 15.71 \\
\hline Reinforcing selected course & 15 & 10.71 \\
\hline Non-official meetings & 9 & 6.43 \\
\hline Conversation with support staff & 7 & 5.00 \\
\hline Preaching during crusades & 6 & 4.29 \\
\hline Academic discussions & 4 & 2.86 \\
\hline Conversation with instructors & 2 & 1.43 \\
\hline Cell phone conversations & 2 & 1.43 \\
\hline Has no role & 6 & 4.29 \\
\hline Total & 140 & 100.00 \\
\hline
\end{tabular}

Table 3: Other Roles of Kiswahili Language in Technical Education Source: Field, 2017 
From table 3 above, the roles exercised by Kiswahili in technical institutions are listed in order of importance as opined by the respondents. Those roles which gravitated towards the technical curriculum included expounding concepts $27.14 \%(n=38)$; guidance counseling 20.71\% ( $n=29)$; use of Kiswahili in service delivery 15.71\% ( $n=22)$; Kiswahili being taught as a subject to students of Social Work and Community Development course in certificate level 10.71\% ( $\mathrm{n}=15)$; academic discussions $2.86 \%(n=4)$ as they prepare for the internal and external examinations.

Furthermore, it can be deduced that, $27.14 \%(n=38)$ of the respondents opined that course instructors used Kiswahili frequently to expound concepts which were beyond students' comprehension. The learners, as revealed by their instructors, could at times, in the middle of a lesson, interrupt and put across questions in Kiswahili for the instructor to clarify what he was presenting. The use of Kiswahili to clarify concepts is not a strange phenomenon because it shows that there is something missing in the system for it to function fully as propagated by the functionalists. Biton, Bonnett, Jones, Lawson, Skinner, Stanworth and Webster (2002) aver that "The health of an organism depends on all the organs that make up its system working properly together, each organ performing a necessary function for the organism's health e.g. body" (Pp. 471). Their views can as well be applicable in the Kenyan situation. When the technical institutes' instructors, codeswitch from English to Kiswahili, it is for the benefit of the conclusion of the lessons and the concepts to be understood clearly by the learners. Just like any living being all the organs depend on each other for the success of a certain task (Eshleman, Cashion, Barbara \& Basirico, 1993). This as well can be reflected in the lesson by the use of Kiswahili where beefing up of the lesson is done and its completeness achieved.

Though Kiswahili is not a medium of instruction in technical institutes, it makes the learners conceptualize ideas. Ipara and Mbori (2009) say "A language serves a symbolic function ... and finally, it determines thought and perception." (Pp. 144). This is true of the certificate students who conceptualize their ideas in Kiswahili and pass them through the same language. So, to them, when they interject their instructors' lessons in Kiswahili, it is a volitional act which indicates there is something incomplete in the system as advanced by the functionalists.

In the technical institutions like in any other educational institutions, students are faced with various challenges. These may range from social, economic and psychological. To deal with these problems, the students and their instructors intimated that Kiswahili language played a very crucial role of guiding and counseling. It appeared this role was important to the students since it was rated second at $20.71 \%(n=29)$ of the total sampled population of 140 respondents. Though the researchers did not have the opportunity to ask why Kiswahili was the preferred language of choice by the counselors during counseling sessions, they concluded that, may be, it was the language which brought them closer to their clients. Mbori (2008) in his research found out that, Kiswahili language brought reconciliation after the Rwanda genocide. The majority of the Rwandese chose Kinyarwanda followed by Kiswahili and not either French or English despite the two languages having many speakers compared to Kiswahili. Though the role Kiswahili language plays is minimally outlined in the curriculum, technical institutes' family seems to have recognized and appreciated it.

Besides the above-mentioned roles Kiswahili plays by the sidelines of the technical education curriculum, it was majorly used in students' academic discussions. 2.86\% $(n=4)$ of the respondents indicated that they used it in discussions when they were preparing for internal and external Kenya National Examinations Council (KNEC) examinations. These discussions build them intellectually, mentally and also unite them. Barnard, Burgess and Kirby (2004) quoting Brown who was an anthropologist said:

If, for example, a group of people are regularly observed sitting around smoking pipes communally, this activity may function to bind together or integrate the group as a community and reinforce the values of friendliness and cooperation" (Pp. 15).

To the functionalists, groupings highlighted by Barnard et al (2004) play a big role in developing and building unity among the technical students apart from the educational role of academic discussions, as they prepare for their examinations whether internal or external.

The discussions among the technical students in Kiswahili instead of English, which is the language of instruction is not surprising as observed by Senkoro (2005) who found out that students in Tanzanian universities and secondary schools used Kiswahili in their academic discussions instead of English which is the medium of instruction. Those findings correspond with Dalvit's (2004) who found out that students in Fort Hare University in South Africa used Isixhosa in their academic discussions. Therefore, students in technical institutes in Kenya are not an exception when using Kiswahili in their academic discussions as opposed to English. This role, in a nut-shell, complements the mainstream curriculum activity and by so doing reflects the importance of Kiswahili in technical education.

Though teaching of Kiswahili as a way of reinforcing Social Work and Community Development course is reflected in certificate students' curriculum, its teaching is peripheral. This is because the students are not examined in the subject. Although it is taught and incorporated in the main stream curriculum, only $10.71 \%(n=15)$ of the 140 respondents rated it fourth in terms of importance. Teaching of Kiswahili to students pursuing Social Work and Community Development, the researchers felt, was a step in the right direction. However, more courses should be taught Kiswahili or preferably Communication Skills in Kiswahili, as a subject, which is more suitable. $15.71 \%(n=22)$ of the respondents opined that Kiswahili was better suited in providing services in the field. Therefore, they felt it was in the interest of effective service delivery that Kiswahili be made the language of service to their clients once posted to various stations after graduation.

Other roles performed by Kiswahili though having social bearing include: non-official meetings among the students $6.43 \%(n=9)$, conversation between the students and support staff $5.00 \%(n=7)$, preaching during crusades $4.29 \%(n=6)$, social conversation with their instructors $1.43 \%(n=2)$ and cell phone conversations $1.43 \%(n=2)$ among themselves, friends and relatives. $4.29 \%(n=6)$ of the respondents said Kiswahili had no role in technical education.

In addition, our findings revealed that Kiswahili was the favorite language of communication among the students. Our respondents were required to state the language they mostly preferred to use among themselves and the results are depicted in figure 2. 


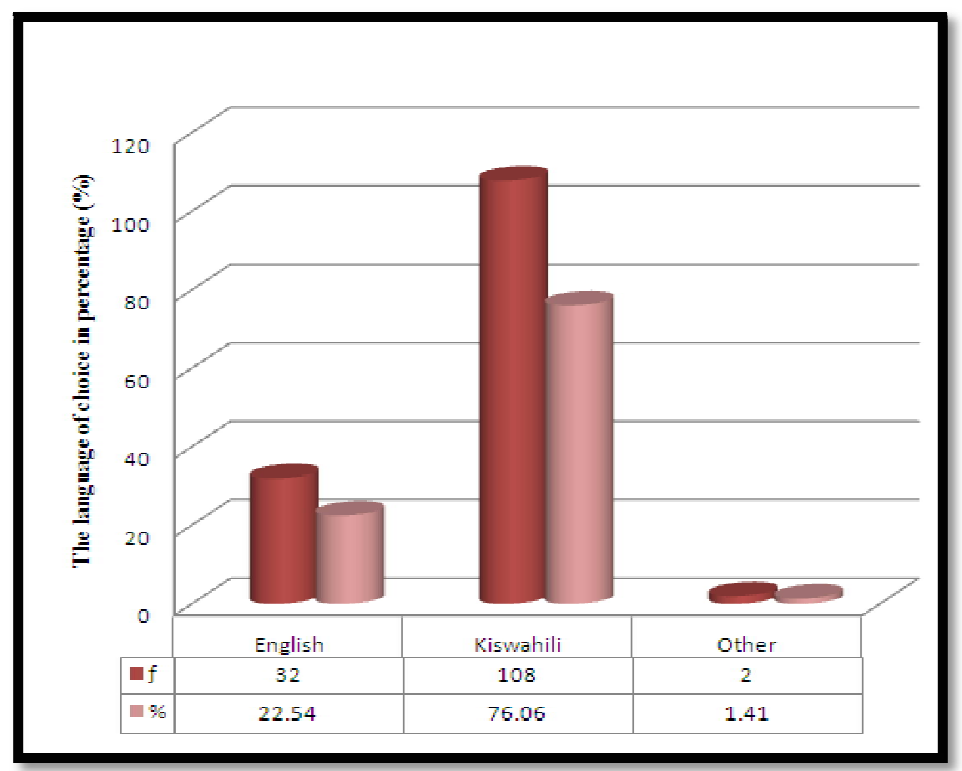

Figure 2: The Language of the Conversation among the Students

Figure 2 above shows the language of choice in communication among the students in technical institutes. It is clear that $76.06 \%(n=108)$ of the students indicated they used Kiswahili for communication purposes during their leisure time. However, 22.54\% ( $n=32)$ preferred to use English, while 1.41\% $(n=2)$ expressed support for the use of vernacular languages. Therefore, a very sizeable population of the students' fraternity used Kiswahili on their own volition. Our study buttresses that of Mohochi (2005) which found out that even when the secondary school students were forced to express themselves in English, they chose to use Kiswahili in spite of the consequences. The practice of controlled language use among Kenyan speakers did not start yesterday as it can be traced to the colonial times (Mohochi, 2005; Nyandwaro, 2015), and may be this is why Chiraghdin and Mnyampala (1977) equated Kiswahili to the mtondo tree which does not rot or sink when immersed in deep waters. This is the case as for Kiswahili in technical institutes in Kenya which remains afloat by appearing along the sidelines of the technical education curriculum. All in all, the students' views are very much reflected in deed and word when they give space to Kiswahili in expounding concepts, guiding and counseling students, used in academic discussions and appreciating it in service delivery; all intertwined in curriculum delivery in technical institutions.

\section{Recommendations}

The major purpose of this study was to find out the importance of Kiswahili language in technical education in Kenya. It was established that despite English language playing an official role in technical education, Kiswahili had a very important function to play in the sidelines of the technical education curriculum. In spite of English being the medium of instruction, Kiswahili buttressed and beefed up the presentations of instructors in various lessons when expounding complex concepts to their learners. Equally, it was used in guidance and counseling sessions by counselors when solving various social problems among the students. It is out of this insight; this study recommends to the Ministry of Higher Education Science and Technology (MOHEST) in collaboration with the Kenya Institute of Curriculum Development (KICD) to see how best they can introduce teaching of Kiswahili language as a subject to all students of technical institutes. By doing so, they will be reinforcing the academic roles Kiswahili plays by the sidelines of the technical education curriculum.

Similarly, as a matter of urgency and as a stopgap measure, the students who are currently pursuing Social Work and Community Development course should be examined in Kiswahili. Also, apart from Social Work and Community Development certificate students, Kiswahili should be taught to students of other service-related courses. These courses are Medical Laboratory Science and Technology, Science Laboratory Technology, General Agriculture, Electrical Engineering, Fashion Design and Garment Making, Hair Dressing and Beauty Therapy, Marketing, Business Management, Sales and Marketing, Social Work and Community Development (diploma students), Cooperative Management, Chain Supply Management, Purchasing and Supplies Management. The Ministry of Higher Education Science and Technology should equally explore the possibility of using Kiswahili language as a medium of instruction at the certificate level, as is the case in Tanzania. In addition, future researchers may try to find out the attitudes of students of technical institutes towards Kiswahili being the language of service delivery in the field. Moreover, attitudes of students per service course vis-à-vis non-service courses towards being taught Kiswahili.

\section{Conclusion}

This study explored the views of students of technical institutes on the roles Kiswahili may play towards technical education. They were of the view that Kiswahili played a very important role in supporting their academic and social activities within their institutions. Some of the academic roles included expounding concepts by instructors, used as a tool in guiding and counseling students, service delivery once posted to the field, academic discussions among the students and also taught as a subject to reinforce the activities of social work graduates in later dates of service. In social circles, students' fraternity use Kiswahili as the language of communication, conversing with support staff and their course 
instructors. More so, it is the language of their choice in crusade preaching and non-official meetings. Generally, this study established that according to the students of technical institutes, Kiswahili played a major role by the sidelines of technical education curriculum and that is why their attitudes are positive towards the language.

\section{References}

i. Amedorme, S. K. \& Fiagbe, Y. (2013). Challenges facing technical and vocational education in Ghana. International Journal of Scientific and Technology Research, 2(6), 253-255. Retrieved from https:/ / www.researchgate.net/ .../303882753_Challenges_Facing_Technical_And_Voc...

ii. Barnard, A.; Burges, T. and Kirby, M. (2004). As Level and A Level: Sociology. Cambridge: Cambridge University Press.

iii. Biton, T., Bonnett, K., Jones, P., Lawson, T., Skinner, D. Stanworth, M., \& Webster, A. (2002). (4thed.) Introductory Sociology. New York: Palgrave Macmillan.

iv. Chiraghdin, S. na Mnyampala, M. (1977). Historia ya Kiswahili. Nairobi: Oxford University Press.

v. City \& Gilds Group (n. d.). Economic benefits of vocational education and training in India. Retrieved from https:/ / www.cityandguildsgroup.com/ / media/ .../ cggroupindia\%20pdf.ashx

vi. City \& Gilds Group (n. d.). Economic benefits of vocational education and training in UK. Retrieved from https:/ / www.cityandguildsgroup.com/ / media/ .../ cggroupUK\%20pdf.ashx

vii. Dalvit, L. (2004). Attitudes of Isixhosa-speaking students at the University of Fort Hare towards the use of Isixhosa as a language of learning and teaching (LOLT) (Master's thesis). Rhodes University, Grahamstown, South Africa.

viii. Eshleman, J. R., Cashion, B. G., \& Basirico, L. A. (1993). Sociology: An Introduction (4th edition). New York: Harper Collins College Publishers Inc.

ix. Habwe, J. (2009). The Role of Kiswahili in the Integration of East Africa. The Journal of Pan African Studies, 2(8), 210. Retrieved from https:/ / www.researchgate.net/... 267949122 The Role of Kiswahili in the Integrati...

x. Ipara, I., \& Mbori, B. (2009). The Role of Kiswahili in Enhancing the Potential of Science and Technology. The Journal of Pan African Studies, 2(8), 139-150. Retrieved from www.jpanafrican.org/ .../2.8_RoleofKiswahilinEnhancingThePotentialOfScienceAndT...

xi. Jackson, S. L. (2009). Research Methods and Statistics: A Critical Thinking Approach (3rded.) Belmont, CA: Wadsworth.

xii. Kandagor, M. (2014). Nafasi ya Kiswahili katika ushirikiano wa Afrika Mashariki. Katika N. Michira, P. I. Iribemwangi \& M. Mbatiah (Wahr.), Ukuzaji wa Kiswahili: Dhima Na Majukumu ya Asasi Mbalimbali (uk. 180-192). Nairobi: Focus Publishers Ltd.

xiii. Kiango, J. G. (2002). Nafasi ya Kiswahili katika Ujenzi wa Jamii Mpya Afrika Mashariki. Retrieved from http:/ / www.qucosa.de/ fileadmin/ data/ qucosa / documents / 10082/ 9 12_kiango.pdf

xiv. Kigwilu, C. P.; Akala, J. W.; \& Wambua, M. J. (2016). Challenges Facing the Effective Implementation of Artisan and Craft Courses in Catholic Sponsored Community Colleges in Nairobi, Kenya, ISOR Journal of Research and Method in Education (IOSR-JRME), Pp 27-36. Retrieved from www.iosrjournals.org

xv. Kihore, Y. M. (1983). Nafasi ya Kiswahili barani Afrika. (D.L.W. Masoko \&J.S. Mdee. Whr.). Makala ya MULIKA. Na. 15, uk. 32-39

xvi. Kimani, E. N., Mueni, E. D. \& Wango, D. M. (2015). Gender-related challenges faced by Students in learning technical courses in Machakos technical institute, Machakos County. Retrieved from https:/ / ku.ac.ke/ schools/ humanities/ index.php/ research/ .../ 88-research

xvii. Kothari, C.R. (2004). Research methodology. New Delhi: New Age Publishers.

xviii. Mbori, B. J. O. (2008, March). The Interface Between Language Attitudes and Language use in a Post-Conflict Context: The Case of Rwanda (Doctoral dissertation, University of South Africa, Pretoria, South Africa) Retrieved from http:/ / uir.unisa.ac.za/ bitstream/ handle/ 10500/ 1733/ thesis.pdf?sequence=1

xix. Mohochi, E. (2005). Mielekeo ya wanafunzi kuhusu lugha ya Kiswahili na athari zake katika matokeo ya mtihani wa Kiswahili wa kidato cha nne katika mikoa ya pwani na Nyanza, Kenya (Tasnifu ya Uzamifu). Chuo Kikuu cha Egerton, Njoro, Kenya.

xx. Mukuthuria, M.(2006). Kiswahili and its Expanding Roles of Development in East African Cooperation: A case of Uganda. Nordic Journal of African Studies, 15(2), 154-165. Retrieved fromwww.njas.hesinki.fi/pdffiles/vol15num2/ mukuthuria.pdf

xxi. Murgor, T. K., Chang'ach, J. K. \& Keter, J. K. (2014). Accessibility of Technical and Vocational Training among disabled people: A survey of TVET institutions in North Rift region, Kenya. Journal of Education and Practice, 5(3), 200-207. Retrieved from https:/ / www.iiste.org/Journals/ index.php/JEP/ article/ viewFile/ 10732/ 10937

xxii. Muyela, J. A. (2012). An Evaluation of the effectiveness of technical education and technical programmes in Kenya: A case study of selected Technical Training Institutes in Nairobi. Retrieved from http://irlibrary.ku.ac.ke/ handle/ 123456789/ 5978

xxiii. Nabea, W. (2009). Language Policy in Kenya: Negotiation with Hegemony, Journal of Pan African Studies, 3, 121138. Retrieved from www.jpanafrican.org/ docs/ vol3no1/3.1\%20Kenya\%20Language\%20Policy.pdf

xxiv. Ngerechi, J. B. (2003). Technical and Vocational Education and Training in Kenya. Retrieved from http:/ / www.bota.org.bw/ docs/ TVET_in_kenya.pdf

xxv. Nyandwaro, K. L. (2015). Mielekeo ya wafanyakazi kuhusu Kiswahili kama lugha rasmi Katika Wizara za serikali nchini Kenya: mintarafu, kaunti ya Kisii (Tasnifu ya Uzamili). Chuo Kikuu cha Kenyatta, Nairobi, Kenya. 
xxvi. Payne, N. (2014, February 28). Seven reasons to pay attention to Swahili language. Africa Business Insight. Retrieved from https:// www.howwemadeitinafrica.com/ seven-reasons-to-pay-attention-to-the-swahililanguage/ 36057/

xxvii. Senkoro, F.E.M.K. (2005, December 6-10). Language of instruction: the forgotten factor in education quality and standards in Africa? Paper presented at the CODESRIA General Assembly Maputo, Mozambique. Retrieved from http:/ / www.codesria.org/ IMG/ pdf/ senkoro.pdf

xxviii. Swaziland Economic Policy Analysis and Research Centre. (2018, April 4). The economic benefits of Technical and Vocational Education and Training (TVET) in the Kingdom of Swaziland: A case of the National Handcraft Training Centre (NHTC): In "Working Paper Series". Policy Briefs. Retrieved from

http:/ / www.separc.co.sz/ 2018/ 03/ 27/ the-economic-benefits-of-technical-vocational-education-and-training-inthe-kingdom-of-swaziland/ .pdf

xxix. Webb, V., \& Kembo-Sure (2000). The Language of Africa. In V. Webb \& Kembo-Sure (Eds.), African voices: an introduction to the languages and linguistics of Africa. (pp. 26-54). Cape Town, South Africa: Oxford University Press South Africa. 